\title{
Living in a Bottomless Pit: Households' Responses to Land Subsidence, an Example from Indonesia
}

\author{
Erlis Saputra' ${ }^{1,2 *}$, Tejo Spit ${ }^{1}$, Annelies Zoomers ${ }^{1}$ \\ ${ }^{1}$ Department of Human Geography and Planning, Utrecht University, Utrecht, The Netherlands \\ ${ }^{2}$ Department of Development Geography, Universitas Gadjah Mada, Yogyakarta, Indonesia \\ Email: *E.Saputra@uu.nl
}

How to cite this paper: Saputra, E., Spit, T. and Zoomers, A. (2019) Living in a Bottomless Pit: Households' Responses to Land Subsidence, an Example from Indonesia. Journal of Environmental Protection, 10, 1-21.

https://doi.org/10.4236/jep.2019.101001

Received: November 26, 2018

Accepted: January 4, 2019

Published: January 7, 2019

Copyright $\odot 2019$ by author(s) and Scientific Research Publishing Inc. This work is licensed under the Creative Commons Attribution International License (CC BY 4.0).

http://creativecommons.org/licenses/by/4.0/

\begin{abstract}
Land subsidence has severe physical and economic implications for both areas and people. Numerous scholars have shown that land subsidence has had massive impacts at global, national and regional levels, and that the impacts were usually responded to by the government. However, little attention has been paid to what land subsidence means to people's daily lives and how much it costs them. To fill that gap, this article draws on empirical research carried out in three areas in Indonesia to provide a better understanding of what land subsidence means to households, and how they respond to the consequences and how much it costs them to do so. An analysis of a survey of 330 households shows that they have been suffering from various severities of impacts of land subsidence for an extended period. Whereas some of the households respond to the impacts by making small preparations or adapting to the damages, others can do nothing due to a lack of money and their continuously declining earning capacity. Thus, the affected households are effectively throwing money into a bottomless pit. We argue that these households must escape the vicious circle caused by land subsidence by increasing their income capacity or even abandoning the affected areas.
\end{abstract}

\section{Keywords}

Land Subsidence, Households, Impacts, Responses, Income Earning Capacity

\section{Introduction}

Land subsidence is a gradual settling or sudden sinking of the earth's surface due to the movement of earth materials [1]. It occurs gradually and has many impacts on both urban and rural areas. It destroys houses and facilities [2] [3] [4], 
damages plantations and their drainage infrastructure [5] and enlarges inundated areas [6] [7]. These impacts cause direct economic losses [4] [8].

The reported economic cost of long-term land subsidence is enormous. For instance, Warren et al. [8] showed that in just 30 years (1943-73), total land subsidence-related costs in Texas (USA) amounted to about US\$ 113.6 million. In Tianjin (China), land subsidence in 2007 led to severe economic losses, amounting to as much as US\$ 18.19 billion [9]. A recent assessment showed that in Arizona (USA), land subsidence had led to a fall in the prices of properties in affected areas [10]. At the household level, land subsidence impacts both directly-in the form of damage to houses, buildings and infrastructures-and indirectly, namely on people's environmental, economic and social status, as the secondary consequences of land subsidence [11].

As land subsidence is massive, affected people should respond to it with all their capacity. People's ability to deal with the impacts is positively correlated with their responses and ability to adapt [12] [13]. The fact that land subsidence happens and affects people for an extended period of time necessitates a proper response and sufficient capacity to adapt. The question then is: can affected households deal with the consequences of land subsidence? The answer to this question is particularly needed, since research on people's responses to and the impacts of land subsidence at the household level is limited. To date, most such assessments have been at a national and regional level or as part of physical impact analyses (e.g. see [14] [15] [16] [17]).

Therefore, this article presents a bottom-up assessment of what land subsidence means to households, how they respond to the consequences and how much they spend on dealing with the impacts. Understanding the impact of land subsidence on the income of affected households is crucial, because a comprehensive analysis of the economic loss can help to improve risk mitigation and reduction or enhance pre-impact prediction [18] [19]. Furthermore, understanding the responses of affected people will reveal their readiness to reduce impacts and their exposure [20]. This article shows how widespread the problems are in three areas of Indonesia that have been suffering unceasingly from land subsidence due to numerous triggers, leading to severe physical and socioeconomic impacts on both the areas and their populations [2] [7] [15] [21] [22] [23] [24] [25].

This article is structured as follows. The following section discusses the concepts of adaptation and adaptive capacity. Section 3 details the research location and research methods. The results are presented in Section 4. The article concludes with a discussion (Section 5) and the conclusions (Section 6).

\section{Adaptation and Adaptive Capacity to Disasters}

People are socially vulnerable if they are exposed to natural hazards but cannot respond to or recover from them [26]. Their vulnerability is also influenced by their inability to cope with pressure on their livelihoods or wellbeing [27]. Thus, 
socioeconomic status is one of the leading factors affecting social vulnerability [28]: the less income affected people have, the more vulnerable they are [29].

The question is, how can such people deal with their vulnerable status? Brooks [13] explains that vulnerability can be reduced through adaptation, which refers to changes in processes and practices to limit potential damage [12]. Reuveny [30] argues that whereas some people adapt to problems by reducing impacts or repairing the damage as a short-term solution, others do nothing. Yet others respond to catastrophes by moving away [31]. However, for reasons related to economic and social relationships, most affected people are reluctant to move [32] [33]. Thus, our research focus was on households that wanted or needed to stay in these areas and thus did not consider relocation.

The responses of affected people who remain in an affected area should be directed towards reducing their vulnerability. Adger et al. [20] explain that an adaptation will be valuable if it reduces impacts and exposure. However, some affected households cannot minimize the impact of disasters because of their limited adaptive capacity, namely their limited ability to adapt to changes [34]. Smit and Wandel [35] and Shaw et al. [34] assert that the adaptive capacity of affected people influences their response. The socioeconomic status of affected people is one of the adaptive capacities that is positively correlated with their ability to decrease their vulnerability [29] [36] [37].

Without neglecting other factors, household income is the focus of this article in representing socioeconomic status. Income determines a household's ability to access money directly when it is needed. The availability of income increases the number of potential responses, which reduces a household's vulnerability [38] [39] [40]. Even though other external resources (e.g. social capital from the extended family or neighbours) are needed, this income, as well as its sustainability, is crucial to covering the recurring costs because it can be accessed when required.

\section{Research Location and Methods}

\subsection{Study Areas}

Data were collected from urban, coastal and peatland areas in Indonesia, namely Jakarta, Semarang City and Indragiri Hilir, respectively (see Figure 1). Various urban, coastal and peatland areas of Indonesia suffer from continuous land subsidence, which will become worse since the activities in these areas are increasing. These case study areas are the areas that experience the highest speed of and most damage from land subsidence, which was determined through a literature study [2] [3] [21] [41], official reports from public authorities and conversations with key persons from local government offices. The different characteristics of the areas promoted the understanding of the various consequences and responses of land subsidence for households.

Urban and coastal areas of Jakarta and Semarang City have long suffered from land subsidence [2] [7] [41]. Groundwater exploitation and construction load 
due to rapid urban development have accelerated land subsidence and increased its impacts [2] [3]. The Indonesia Climate Change Sectoral Roadmap (ICCSR) report shows that due to land subsidence combined with sea level rise and higher tides, by 2100 most of the coastal areas in Jakarta and Semarang will be under $5 \mathrm{~m}$ of seawater, while the coastline will have receded by up to $10 \mathrm{~km}$ [42]. Furthermore, rural peatland areas, such as Indragiri Hilir, are being overexploited for large-scale oil and coconut palm plantations, which leads to an influx of more people [43]. The peatland conversion for plantations, followed by drainage, has increased carbon dioxide emissions [44], which lead to peat subsidence [21] [24]. Table 1 shows how severely these areas are affected by land subsidence.

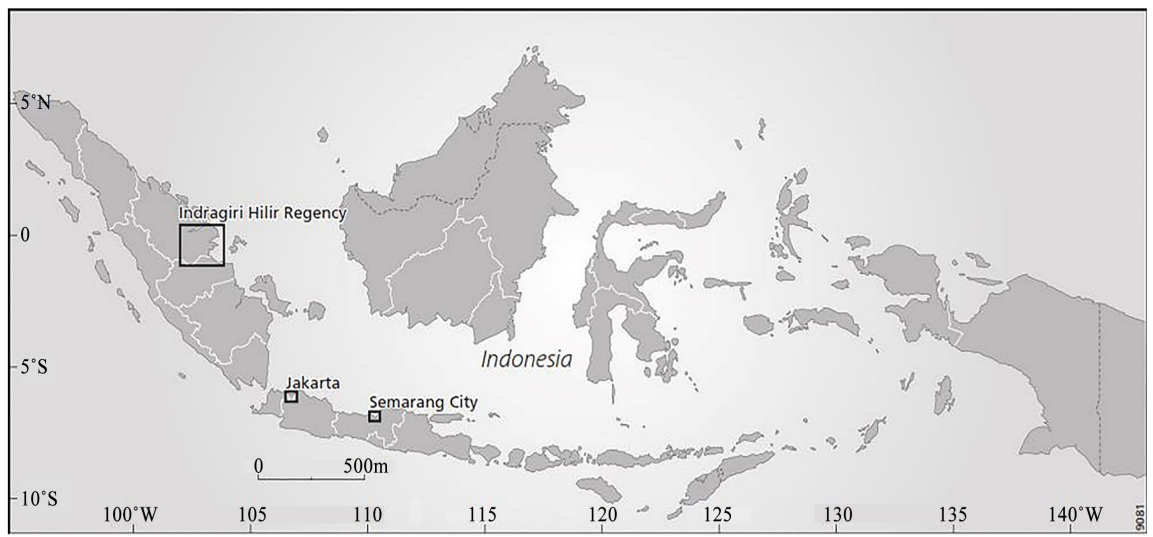

Figure 1. The study areas: Jakarta, Semarang City and Indragiri Hilir.

Table 1. Land subsidence in the case study areas.

\begin{tabular}{|c|c|c|c|c|c|c|}
\hline Case study area & Characteristics & $\begin{array}{l}\text { Sampling area } \\
\text { (sub-districts) }\end{array}$ & $\begin{array}{l}\text { No. of } \\
\text { respondents }\end{array}$ & $\begin{array}{l}\text { Land } \\
\text { subsidence rate }\end{array}$ & $\begin{array}{l}\text { Land } \\
\text { subsidence triggers }\end{array}$ & $\begin{array}{l}\text { Land } \\
\text { subsidence } \\
\text { impacts }\end{array}$ \\
\hline $\begin{array}{l}\text { Jakarta (urban } \\
\text { and coastal area) }\end{array}$ & $\begin{array}{l}\text { One of the world's } \\
\text { megacities } \\
\text { Population density: } \\
15,052 \text { people } / \mathrm{km}^{2} \\
\text { Annual population } \\
\text { growth: } 1.11 \%\end{array}$ & $\begin{array}{l}\text { Cengkareng, } \\
\text { Penjaringan, } \\
\text { Tanjung Priok }\end{array}$ & 90 & $\begin{array}{l}1-15 \mathrm{~cm} / \text { year; } \\
\text { in some areas } 25-2 \\
\mathrm{~cm} / \text { year [3] }\end{array}$ & $\begin{array}{l}\text { Groundwater } \\
\text { extraction, } \\
\text { construction load, } \\
\text { natural consolidation } \\
{[3]}\end{array}$ & $\begin{array}{l}\text { Cracking of } \\
\text { permanent } \\
\text { infrastructure, } \\
\text { expansion of } \\
\text { inundated areas, } \\
\text { increasing inland } \\
\text { seawater intrusion } \\
\text { [3] }\end{array}$ \\
\hline $\begin{array}{l}\text { Semarang City } \\
\text { (coastal area) }\end{array}$ & $\begin{array}{l}\text { Located on an alluvial } \\
\text { plain } \\
\text { Population density: } 4373 \\
\text { people } / \mathrm{km}^{2} \\
\text { Annual population } \\
\text { growth: } 1.71 \%\end{array}$ & $\begin{array}{l}\text { Genuk, } \\
\text { Semarang Utara, } \\
\text { Tanjung Mas, Tugu }\end{array}$ & 124 & $\begin{array}{l}8-13.5 \mathrm{~cm} / \text { year } \\
\text { [7] [40] }\end{array}$ & $\begin{array}{l}\text { Groundwater } \\
\text { extraction, alluvium } \\
\text { soil consolidation, } \\
\text { construction load [2] }\end{array}$ & $\begin{array}{l}\text { Damage to urban } \\
\text { infrastructures, } \\
\text { coastal inundation } \\
\text { [2] }\end{array}$ \\
\hline $\begin{array}{l}\text { Indragiri Hilir } \\
\text { (peatland area) }\end{array}$ & $\begin{array}{l}\text { Intensive expansion of } \\
\text { oil and coconut palms } \\
\text { Population density: } 60 \\
\text { people/ } \mathrm{km}^{2} \\
\text { Annual population } \\
\text { growth: } 1.92 \%\end{array}$ & $\begin{array}{l}\text { Enok, Tembilahan, } \\
\text { Tembilahan Hulu, } \\
\text { Batang Tuaka, } \\
\text { Tempuling }\end{array}$ & 116 & $4-6 \mathrm{~cm} /$ year [20] & $\begin{array}{l}\text { Intensive agricultural } \\
\text { activities-mainly oil } \\
\text { and coconut palm [23] }\end{array}$ & $\begin{array}{l}\text { Damage to houses, } \\
\text { infrastructures and } \\
\text { plantation areas [20] }\end{array}$ \\
\hline
\end{tabular}




\subsection{Data Collection and Presentation}

This survey research combines a qualitative and a quantitative approach, known as mixed-method research [45]. In this method, the two approaches complement each other by minimizing inaccurate findings [46]. This article combines the use of qualitative and quantitative data and methods to answer the research questions.

Data were collected through surveys over a three-month period in 2015. During the surveys, in-depth interviews with respondents were carried out. A two-stage sampling method was used to select the respondents. In the first stage, three areas that represent urban, coastal and peatland were chosen. Then, in the second stage, random sampling was used to select households in the three areas to be interviewed and to complete the questionnaire. In these surveys, the household was the analyses unit, and its head was the respondent (or, if the latter was absent, the spouse of the head of household). Before selecting the respondents, local community leaders in the case study areas were interviewed to discuss the proposed respondents, that is, who were most prone to and affected by land subsidence, and ways to interact with them. In all, 330 respondents in 12 sub-districts from all case study areas were selected as the respondents. This led to 90, 124 and 116 households in Jakarta, Semarang City, and Indragiri Hilir, respectively, being interviewed for between 30 and 45 minutes. The respondents were asked about what land subsidence means to households, how they respond to the consequences and how much they spend on dealing with the impacts.

Land subsidence has both direct and indirect physical impacts on households [11]. These impacts were adopted and combined to define the impacts of land subsidence on affected households in the case study areas. Impacts were categorized as either single types of impact or multiple types of impact. The multiple types of impact were seen as the stronger impacts, since they were caused not only by land subsidence but also by other hazards. Some households suffered from a single type of impact whereas others suffered from multiple types.

Furthermore, the responses of the affected households to the impacts were classified according to the response categories established by Reuveny [30]: 1) stay put and do nothing, accepting the cost; 2) stay put and mitigate the changes; or 3) leave the area. A modification was made by dividing the mitigation part into two, namely repairing and adapting to the damage. The survey collected households' responses from the first time that they had experienced land subsidence.

In addition, to define the cost of dealing with the impacts incurred by affected households, we used and modified the classification of the cost of disaster developed by Mechler and Bouwer [47], which divides the cost into damage costs or losses, adaptation costs and residual costs. The adaptation costs and damage costs (or the decrease in earning capacity) were used in this article. Adaptation costs were determined from the costs of the adjustments, while the decrease in earning capacity was derived from the consequences for household's sources of 
income, such as ponds, oil and coconut palm plantations, and fishing grounds. The household income was used to represent the socioeconomic capacity of the affected household to deal with the impacts of land subsidence.

Data were analysed using quantitative and qualitative methods. The quantitative data were processed using SPSS Statistics software to reveal the distribution of the severity of impacts of land subsidence on affected households, the cost of their responses to land subsidence, and their loss of income due to land subsidence. Furthermore, the qualitative data were manually grouped into their thematic analyses, which were used to support the quantitative analyses. Some of the data were presented in the form of respondents' quotations.

\section{Results}

This section first presents the impact of land subsidence on households and then discusses the range of responses to the impacts and their loss of income, which was influenced by land subsidence.

\subsection{Impacts of Land Subsidence on Households}

Of the 330 surveyed households, 291 (88\%) had been suffering from various direct and indirect impacts of land subsidence for various lengths of time. The direct impacts were in the form of damage to houses, plantations, ponds, mangroves and land (Figures 2(a) and Figure 2(c)). Damage to houses was mainly in the form of the subsiding, tilting or cracking of walls and floors, and the infiltration of water from beneath floors. In addition, numerous pond owners in coastal areas had suffered damage to their ponds, leading to the escape of fish, crabs and prawns. The indirect impacts were on the environment and social status, such as the expansion of daily inundation (Figure 2(b)), the worsening of annual flooding impacts in rural peatland areas, the lowering of the groundwater level and a decrease in the value of properties. Other indirect consequences were health and psychological problems, which were the effects of the daily inundation and unhealthy houses. The impacts had become worse the longer people had been affected by subsidence. One respondent in Semarang City said: "We have been experiencing sinking for years. Our house was damaged; the seawater floods our house every day. It is becoming deeper year after year. The longer we live here, the more severe the flooding".

The severity of the impact of land subsidence on households was diverse. Although some households had suffered only a single type of impact, most had suffered multiple impacts (see Table 2). For instance, the subsided settlement in the coastal area had also suffered from permanent inundation, since the area is also affected by the rise in sea level. Using this logic in our case study areas, the households in the coastal areas of Semarang and Jakarta had suffered from a strong impact because the households were also prone to other hazards, such as tidal inundation and sea level rise. The combination of these hazards with land subsidence had caused households to suffer from the enlarged inundated area. 
This finding supports those of Wang et al. [6] and Warren et al. [8], who showed that the combination of coastal flooding, sea level rise and land subsidence had caused a permanent inundation.

Our finding showed that in different geographical areas, the impacts of land subsidence were also different. Their association with activities in such areas and the existence of other hazards also influenced the variation of the impacts.

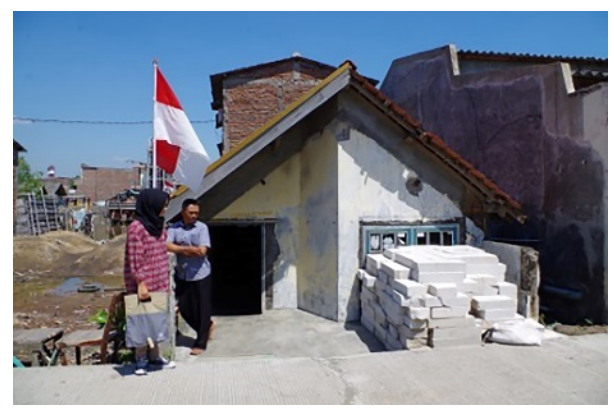

(a)

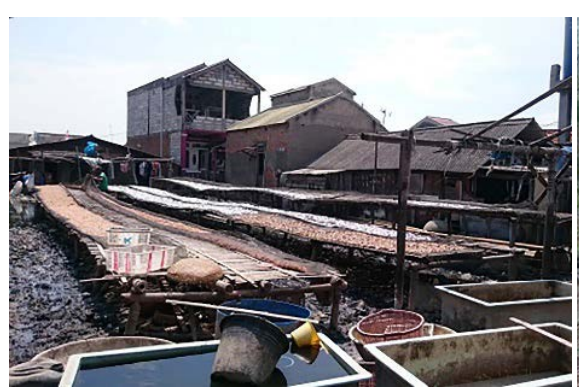

(b)

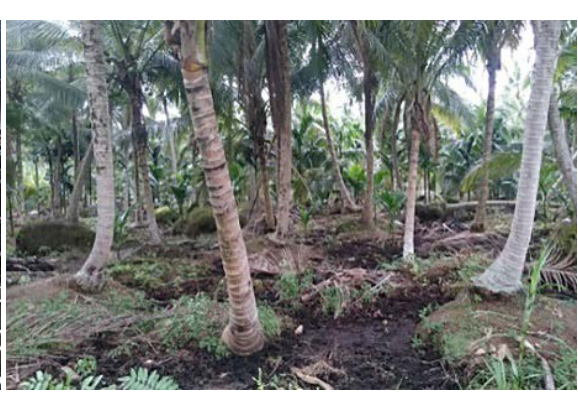

(c)

Figure 2. Impacts of land subsidence (2015): (a) Subsided house (Tanjung Mas, Semarang City); (b) Daily inundation (Penjaringan, Jakarta); (c) Damaged plantation (Enok, Indragiri Hilir).

Table 2. Percentage of affected households based on the severity of impacts.

\begin{tabular}{|c|c|c|c|c|}
\hline \multirow{2}{*}{ Location } & \multirow{2}{*}{$\begin{array}{l}\text { Rate of land } \\
\text { subsidence }\end{array}$} & \multicolumn{2}{|c|}{ Severity of and the most common impact(s) } & \multirow{2}{*}{$\begin{array}{l}\text { Number of } \\
\text {-affected } \\
\text { households }\end{array}$} \\
\hline & & Single type of impact & Multiple types of impact & \\
\hline Jakarta & $\begin{array}{l}1-28 \\
\mathrm{~cm} / \text { year }\end{array}$ & $\begin{array}{l}20.2 \% \text {; expansion } \\
\text { of daily inundation/ } \\
\text { flooding }\end{array}$ & $\begin{array}{l}79.8 \% \text {; damage to the house, } \\
\text { expansion of daily inundation, } \\
\text { damage to ponds/garden/paddy } \\
\text { field }\end{array}$ & 89 \\
\hline $\begin{array}{l}\text { Semarang } \\
\text { City }\end{array}$ & $\begin{array}{l}8-13.5 \\
\mathrm{~cm} / \text { year }\end{array}$ & $\begin{array}{l}14 \% \text {; damage to the } \\
\text { house }\end{array}$ & $\begin{array}{l}96 \% \text {; damage to the house, expansion } \\
\text { of daily inundation, damage to ponds/ } \\
\text { plantation, damage to mangrove, } \\
\text { health problems }\end{array}$ & 121 \\
\hline $\begin{array}{l}\text { Indragiri } \\
\text { Hilir }\end{array}$ & $\begin{array}{l}4-6 \\
\mathrm{~cm} / \text { year }\end{array}$ & $\begin{array}{l}71.6 \% \text {; mostly } \\
\text { damage to the } \\
\text { house or plantation }\end{array}$ & $\begin{array}{l}28.4 \% \text {; damage to the house, } \\
\text { expansion of inundated area, } \\
\text { damage to plantation }\end{array}$ & 81 \\
\hline Total & & $32 \%$ & $68 \%$ & 291 \\
\hline
\end{tabular}

Source: questionnaire analyses (2015). 


\subsubsection{Impacts of Land Subsidence on Households in Urban Areas: Jakarta}

In urban and coastal areas of Jakarta, most of the affected households had been experiencing subsidence for 15 - 25 years. Most of the properties and land of the households had sunk about $100-150 \mathrm{~cm}$, and some had sunk as much $200 \mathrm{~cm}$.

Of all of the affected households, about two fifths had suffered a single type of impact, namely the expansion of either flooding or the daily inundation. In some areas of Jakarta that were far from the coast but close to the river, the affected households suffered mostly from damage to the house (i.e. subsided) or the deepening of flooding from the river surrounding the area or runoff from the rain. The affected households in the coastal area had experienced the expansion of the daily inundation.

Furthermore, the rest (i.e. more than three fifths) had suffered multiple types of impact (Table 2). The impacts were a combination of direct and indirect impacts, which were mainly damaging to houses, followed by the expansion of the inundated or flooded area. It was mostly the affected households in the two sub-districts of Tanjung Priok and Penjaringan that experienced these impacts. In addition, about $7 \%$ of affected households in Cengkareng had suffered damage to their houses and plantations (i.e. garden or paddy field).

\subsubsection{Impacts of Land Subsidence on Households in Coastal Areas: Semarang City}

The households in Semarang City had suffered the most since most households had been experiencing subsidence for about 25 years. Of the affected households, just less than one fifth had experienced a single type of impact; the rest had suffered multiple types (Table 2).

The impacts of land subsidence in coastal areas are the most severe, since such impacts are aggravated by coastal erosion and the rise in sea level. This is why in Semarang we found that land subsidence had drowned a vast number of ponds and mangrove ecosystems, which had been sources of income for many of the affected people. In addition, the combination of those hazards had also increased the frequency, volume and depth of inundation. Worsened by the unsanitary condition of their houses and the drainage around the settlement, the inundation had caused health problems for 47 households. The inundation was always followed by rubbish flowing from the sea into the settlement. Most members of the households, mainly the children, suffered from skin diseases, diarrhoea and breathing problems. A respondent in Tanjung Mas told us: "Land subsidence causes our house to be flooded by seawaterevery day. The water is dirty. My children get itchy".

At the sub-district level, households in Genuk, Tanjung Mas and Tugu had suffered even more because most of them had experienced very severe impacts, namely damage to houses, followed by the expansion of the daily inundation, damage to ponds and health problems. To make the impacts more complicated, in Tanjung Mas and Genuk almost all affected households have two inundations a day, as a result of land subsidence combined with sea level rise and coastal ero- 
sion. The respondents indicated that inundation is becoming more severe, more extensive and deeper due to the continual sinking of their houses. Thus, the other hazards have made the impacts of land subsidence bigger and more serious.

\subsubsection{Impacts of Land Subsidence on Households in Peatland Area: Indragiri Hilir}

Households in the rural peatlands of Indragiri Hilir had mainly suffered from a single type of impact, namely damage to their houses or plantations (Table 2). The damage to the houses was mostly in the form of the houses and their piles sinking or tilting. Most of the sinking houses were located in the plantations that were surrounded by drainage channels. Because most of the affected households had been suffering from land subsidence for only 5 years and most of their houses and plantations had sunk only about $40 \mathrm{~cm}$, land subsidence had had a minimal impact, compared with other areas. Thus, the low level of the severity of the impacts was influenced by the short duration and slow rate of land subsidence.

The damage to plantations and the expansion of inundated areas also had a severe impact on the households. Almost all of the plantation areas around the river of Indragiri suffer from the highest annual flood (the pasangkeling). Our interviews revealed that the inundated and flooded areas around the plantations were expanding year by year, triggered by the gradual sinking of the plantations. Regarding the damage to plantations, a peasant in Enok stated: "The land on my plantation is sinking. The roots of the coconut palms are exposed higher above the ground than when I planted them". In addition, peat subsidence in the plantation had also caused the coconut and oil palms to lean and die off, and the drainage channels were breached. Therefore, in peatland areas, land subsidence had seriously damaged not only houses but also plantations, which are the source of income of many affected households.

\subsection{Responses of Affected Households to the Impacts of Land Subsidence}

Considering the repeated and severe impacts of land subsidence on the affected households over an extended period of time, we expected that all of them (291 households) would have responded to the impacts effectively. However, we found that just a little over half of them (55.3\%) had taken measures. Thus, in responding to the impacts of land subsidence, the affected households were categorized into 1) those who either did nothing or made small repairs and 2) those who adapted to the damages.

\subsubsection{Do Nothing or Repair the Damage}

The households that regarded the impacts as severe but did not have enough money to take adaptation measures and those that regarded the impacts as not yet important enough to be responded to (i.e. they intended to make some adjustments after more significant impacts occur), had decided to do nothing or to make small repairs. 
Of the affected households, about 44.7\% (130 households) had not responded to the impacts as they lacked the money to do so. A respondent in Semarang City told us: "My house is sinking every year. About 15 years ago, I couldn't touch my rooftop, but now I can! I don't have enough money to raise the roof. I'll wait for several years, and then see what I can do". Furthermore, households that had suffered multiple types of impact were not inclined to adapt to the problems. Our research indicated that of the households that had not responded, $60 \%$ had suffered from strong impacts.

However, about $9.3 \%$ of the affected households (27) had repaired the damage to their assets. The house was always given priority. When they repaired their houses, most had used the same materials that were used when their houses were first built. For instance, those whose houses are permanent had repaired the damage using similar materials (i.e. concrete), which were brought in from outside the area or reused from the ruins of abandoned houses. Those who lived in wooden stilt houses had replaced broken piles with the same kind of pile. They also changed their floors gradually. To minimize the cost, some households in Tembilahan Hulu and Tempuling collected wood from the surrounding forest to modify their floors and piles.

Fixing the damaged plantation was also the concern of the affected households that lived in peatland areas. They repaired the damaged drainage channels and restored the damaged oil and coconut palms. The repair of the drainage channels had mainly been a matter of plugging the leaks, whereas the restoration of the palms was focused on supporting them. A peasant in Enok stated: "Some parts of the channels have been damaged. It was even worse when the highest annual flooding occurred. I used to rebuild the channels after the flood ended. My friends used to help me".

\subsubsection{Adapt to Damage}

The households that responded to the impacts also invested in some adaptation measures, such as elevating or modifying their houses and optimizing the plantation channels. The 134 affected households that had taken some structural measures to adapt to the damage had chosen measures to prevent worse consequences in the coming 5 to 10 years. Most of those who had adjusted their houses were households whose houses had already sunk $100-250 \mathrm{~cm}$. They had also been experiencing annual floods and daily inundations for years.

To adapt to the damage to houses, all had raised or modified their floors, walls and/or roofs. To raise their houses, some households had brought in sand from outside the area, while others had used rubble from abandoned houses. In addition, some households whose houses had already sunk $250-450 \mathrm{~cm}$ also raised their walls and roofs. This measure had to be done because the houses had become uninhabitable. A respondent in Genuk told us: "As our house wall had cracked badly and the house had been very low, we raised not only the floor but also the roof and wall". Raising the walls and roof was the last resort after a house was no longer habitable. 
Figure 3 shows an example of a new house built on the former roof, which is now the foundation of the house. The house was built on the former roof because the original house had been destroyed. It was rebuilt to prevent seawater from the daily inundation entering the house. Figure 4 shows the wall and roof that had been raised because the original house had become too low and thus uninhabitable.

Furthermore, in a limited number of cases, affected households in rural peatland areas of Indragiri Hilir had modified their houses by using stronger wooden piles together with cement inside the buildings' foundations. This minimizes fissures in the foundations due to land creep during subsidence and increases their elasticity. In addition, due to an unstable peatland condition and land creep during land subsidence process, almost all affected households that lived in stilt houses replaced some of the house piles. This happens almost every year. To avoid having to do so, some households used a stronger wood (ironwood).

Still, in peatland areas, the affected households tried to adapt to damage to the plantations by optimizing the drainage. A limited number of them had dug gullies and elevated the dams in the channels to prevent water from flooding the plantations; a few others had dredged sediment from the channels. Even though some adaptation measures had been taken to protect plantations, our survey found that the problems remain.

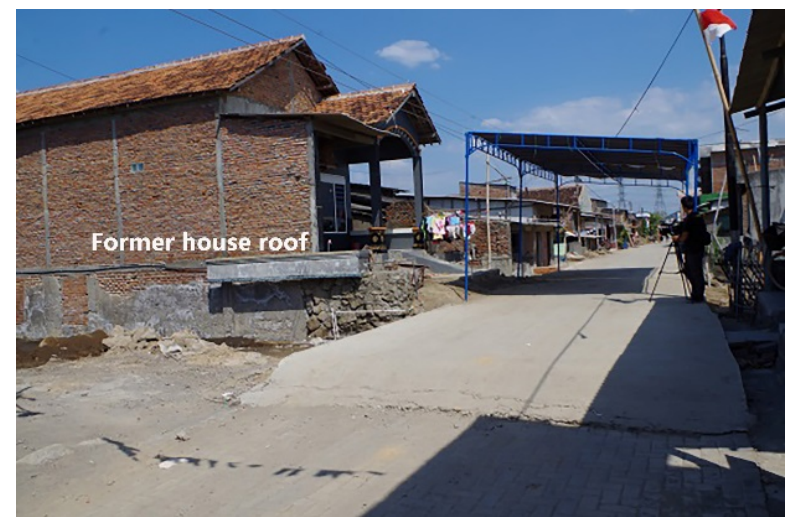

Figure 3. Elevated floor to protect against daily inundation.

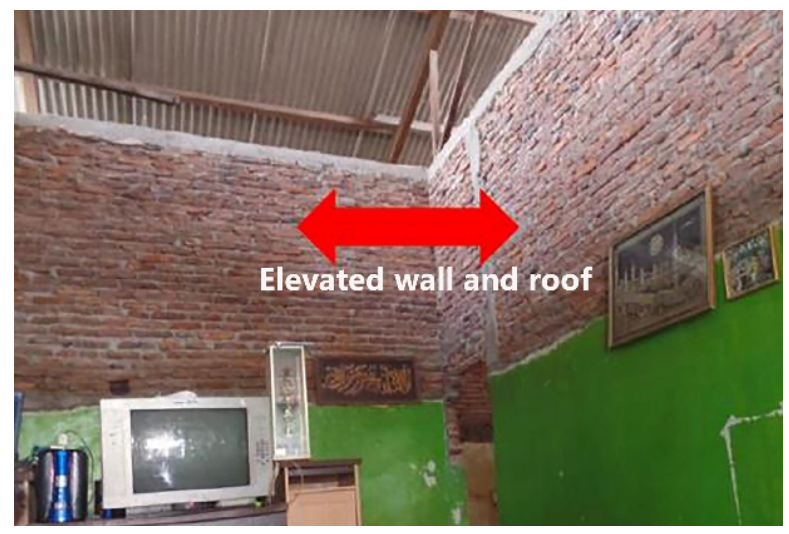

Figure 4. Raised wall and roof of a previously damaged house. 


\subsection{Impact of Land Subsidence on Households' Income}

Most of the measures discussed above cost money. We expected that the income of the affected households would be enough to cover the cost of the measures. However, we found that the income of some affected households was even lower due to the increase in the expenditure as the cost of responses and the decrease of earning capacity.

\subsubsection{The Increase in Expenditure}

Of the affected households, 120 had spent money on repairing and adapting to the damage. In 2015, each household spent on average about US\$ 107 on repairing the damage-which was about a quarter (28\%) of their average total annual expenditure (US\$ 382) (see Table 3). This table also shows that the households in the coastal areas of Semarang had spent more on repairs than those in rural peatland areas of Indragiri Hilir, namely an average of US\$ 113 (40\% of average total expenditure) vs US\$105 (26\%). This high percentage is a result of the more severe impacts in coastal areas and of the combination of land subsidence and other coastal hazards, such as sea level rise and coastal erosion. The amount of money spent by the households differed according to the type and degree of damage, the materials used and the availability of money.

To adapt to the damage, every household had spent on average about US\$ 172 (32\% of their average total expenditure). Households in the rural peatlands of Indragiri Hilir spent more than those in other areas, namely about $49 \%$ of their average total annual expenditure (US\$ 308) (see Table 3). Households in coastal and urban areas had also had spent a significant portion of their total expenditure on adaptations, namely about $43 \%$ in Semarang City and $20 \%$ in Jakarta. Thus, the affected households had allocated at least one fifth of their entire expenditure to adapting to the impacts of subsidence.

To summarize, the affected households that had responded had spent an enormous amount of money doing so, especially compared to the total amount of money they spend over their lifetimes. Responding to the damage caused by land subsidence might not solve the problem, however, as affected households will have to continue spending money on various measures.

Table 3. Cost of response to impacts of land subsidence in 2015.

\begin{tabular}{|c|c|c|c|c|c|c|}
\hline \multirow[b]{3}{*}{ Location } & \multicolumn{6}{|l|}{ Type of response } \\
\hline & \multicolumn{3}{|l|}{ Repair the damage } & \multicolumn{3}{|l|}{ Adapt to the damage } \\
\hline & $\begin{array}{l}\text { Average repair } \\
\text { costs per } \\
\text { household (US\$) }\end{array}$ & $\begin{array}{l}\text { Average total } \\
\text { expenditure per } \\
\text { household (US\$) }\end{array}$ & $\begin{array}{l}\text { Avg. repair costs as a } \\
\text { percentage of avg. total } \\
\text { expenditure }\end{array}$ & $\begin{array}{l}\text { Average adaptation } \\
\text { cost per household } \\
\text { (US\$) }\end{array}$ & $\begin{array}{l}\text { Average total } \\
\text { expenditure per } \\
\text { household (US\$) }\end{array}$ & $\begin{array}{l}\text { Avg. adaptation costs } \\
\text { as a percentage of avg. } \\
\text { total expenditure }\end{array}$ \\
\hline Jakarta & - & - & - & US\$ 110 & US\$ 537 & $20 \%$ \\
\hline Semarang City & US\$ 113 & US\$ 283 & $40 \%$ & US\$ 232 & US\$ 536 & $43 \%$ \\
\hline Indragiri Hilir & US\$ 105 & US\$ 405 & $26 \%$ & US\$ 308 & US\$ 630 & $49 \%$ \\
\hline $\begin{array}{l}\text { Total } \\
(\mathrm{N}=120)\end{array}$ & US\$ 107 & US\$ 382 & $28 \%$ & US\$ 172 & US\$ 541 & $32 \%$ \\
\hline
\end{tabular}

Source: questionnaire analyses (2015). 


\subsubsection{The Decrease in Income Earning Capacity}

Of the 291 affected households, the capacity of 110 households to earn income had been reduced due to damage to their sources of income. Land subsidence had ruined their primary sources of income, such as ponds, oil and coconut palms, and fishing grounds. It had also undermined the secondary sources of income of some affected households, especially those whose primary work was related to the affected area, such as pond owners and peasants. Even households whose primary jobs were not affected, such as civil servants, entrepreneurs and employees, had been affected by land subsidence as it decreased their income from secondary jobs as, for example, farm workers or fishermen. For those reasons, the average loss of income in 2015 was about US $\$ 113$ per household, or $5.3 \%$ of their average total income (US\$2152) (see Table 4). Thus, the decrease in earning capacity of the affected households had limited their choice of responses.

\section{The decrease in income earning capacity of households in Jakarta}

In urban and coastal areas of Jakarta, every affected household had lost an average of about US\$ 59 of its income (in 2015), which is less than the amount lost by households in other areas. Of the 36 affected households, eight had lost income from their main jobs and 28 others had lost income from their secondary jobs. A respondent in Penjaringan whose secondary job was assisting fishermen told us: "We used to catch a lot of fish around the mangroves. Now, many mangroves have been damaged. Land subsidence damaged their roots. There are only a few fish left". As the income of the fishermen dropped, so did that of this respondent.

The decrease in income earning capacity of households in Semarang City

The affected households in coastal areas of Semarang City had suffered the most significant average loss of income compared to those in other areas, namely US $\$ 151$ or $9.7 \%$ of average total incomes. One of the triggers of this significant number is that almost half (30 out of 62) of the affected households in these areas depend on fishing. Fishing is one of the jobs most prone to land subsidence, as subsidence directly affects fishermen through the decrease in their production. A fisherman in Tugu told us that:

Table 4. Affected households' loss of income due to land subsidence in 2015.

\begin{tabular}{ccccc}
\hline Location & $\begin{array}{c}\text { Number of } \\
\text { households that } \\
\text { lost income }\end{array}$ & $\begin{array}{c}\text { Average loss of } \\
\text { income per } \\
\text { household (US\$) }\end{array}$ & $\begin{array}{c}\text { Average total } \\
\text { income per } \\
\text { household (US\$) }\end{array}$ & $\begin{array}{c}\text { Avg. loss of income as } \\
\text { a percentage of avg. } \\
\text { total income }\end{array}$ \\
\hline Jakarta & 36 & US\$ 59 & US\$2869 & $2.1 \%$ \\
Semarang City & 62 & US\$ 151 & US\$ 1553 & $9.7 \%$ \\
Indragiri Hilir & 12 & US\$ 79 & US\$ 3098 & $2.6 \%$ \\
Total & 110 & US\$ 113 & US\$ 2152 & $5.3 \%$ \\
\hline
\end{tabular}

Source: questionnaire analyses (2015). 
"The mangrove forest was destroyed by land subsidence and coastal erosion. We hardly find any fish or crabs near the damaged mangroves". The damage to mangroves caused by land subsidence was indicated as the main factor that reduced the quantity of fish caught. In coastal areas of Semarang City, the impacts of land subsidence on mangroves were accelerated by coastal erosion.

Pond owners had also lost income as a result of damage to their ponds. A pond owner in Genuktold us: "Our ponds always inundate a couple of times a year. Many fish and prawns escape from the ponds when the seawater covers it. We believe land subsidence worsens the problem".

An important remark is that in coastal areas, it is difficult to separate the costs caused purely by land subsidence from the costs caused by other coastal hazards. The costs of land subsidence are always accompanied by the costs of the impact of sea level rise, coastal erosion and/or coastal flooding. However, as mentioned in the impact section, land subsidence itself directly costs the affected households or indirectly increases the costs of indirect impacts. In short, land subsidence often increases the costs by strengthening the impacts of other coastal hazards.

The decrease in income earning capacity of households in Indragiri Hilir

In the rural peatlands of Indragiri Hilir, each household had suffered a loss of income of about US\$79, on average. This resulted from damage to their sources of income, such as oil and coconut palms. Some palms were leaning due to the sinking and unstable ground, which had reduced production. The income not only of peasant farmers but also of farm workers was affected, because the decrease in the productivity of coconut or oil palm led to a decrease in the working hours of the farm workers. Thus, due to the high dependence of the peasants and farm workers on the plantations, the continual damage to plantations will make it difficult to save money to deal with the problems.

\section{Discussion}

Land subsidence had affected almost all of the households in various ways, ranging from physical damage to their land and properties, to environmental and socioeconomic problems, for example the undermining of their income. Many had suffered from multiple types of impact. The affected households consistently stated that their assets are continuously sinking, and increasingly so. In the future, the affected households in coastal areas will suffer the most because they also experience other coastal hazards. The combination of land subsidence with other hazards, such as tidal flooding and sea level rise, exacerbates the impacts of land subsidence [2] [32]. A study by Bappenas [42] also shows that a combination of coastal hazards-in their case, receding coastlines and expanding inundated areas-exacerbates problems for households.

In the urban and coastal areas studied, the land subsidence problems may well continue to worsen, as the populations and physical developments in those areas are growing rapidly [48] [49]. Furthermore, land subsidence in rural peatland 
areas will accelerate, since the utilization of peatland for agricultural activities is continuing. Thus, the affected households will remain vulnerable to land subsidence.

To deal with their vulnerable status, the affected households must make an adequate response. However, almost half of them have not done so, despite the severe damage they have suffered. Why did they not respond? According to Yohe and Tol [40], whether affected people take measures to reduce their vulnerability depends on their access to funds. In our case, we found that the lack of income was one of the factors behind their failure to respond. The head of a household in Tanjung Mas told us: "My house sinks severely every year. About 15 years ago, I couldn't touch my rooftop, but now I can! But, I don't have enough money to raise the roof". Many scholars argue that the availability of and access to money are vital to reduce vulnerability to the risks and to determine the success of adaptations [29] [36] [37] [38] [39] [50].

Other households had not responded because they were waiting for more significant damage to their properties before responding in a particular way. Both households that had been subject to a slow rate of light subsidence and those that had been subject to a fast rate of severe subsidence gave this reason. The main reason for ignoring the impacts differed from household to household, but it depended on the severity of the impacts and the rate of land subsidence. For instance, the head of a household in the coastal area of Tugu (Semarang), whose house had sunk about $50 \mathrm{~cm}$, said that he had not yet taken any action because he believed that damage that is more significant would occur in the next couple of years. Instead of repairing it repeatedly, he preferred to respond to the damage in one go, namely after more significant damage occurs. Another respondent in coastal Tanjung Mas (Semarang), whose house had sunk about $100 \mathrm{~cm}$ but had done nothing, said that he will wait till his present house has been destroyed and then build a new one. Therefore, the affected households that delayed taking measures perceived land subsidence as a bottomless pit.

A little over half (55.3\%) of the affected households had responded to the impacts of subsidence, not only by repairing the damage but also by adapting to it. This finding supports Reuveny [30], by adding that in responding to a long-term disaster, households not only prevent impacts by adapting to the damage but also take a small and immediate measure: they repair the damage. A significant difference between these two responses is that repairing is a reactive activity while adapting is a proactive strategy to prevent future] impacts. This finding concurs with Paavola and Adger [51] and Füssel [52], who found similar types of responses by affected people in the face of climate change.

The affected households believe that by responding to the damage, the problem can be solved. However, we found that this type of measure was ineffective. Many households had attempted to adapt to future damage, but their responses had somehow been of no use. Most households had taken measures to repair or adapt their houses, and only limited measures to repair the damage to their sources of income, namely plantations or ponds. In addition, the wrong choice 
of building materials when repairing the damage had also made their measures ineffective. For instance, when raising their houses, only a few households in coastal areas had used lighter materials, such as wooden planks or corrugated roofing sheets. Most had used ceramic tiles for their floors, bricks and cement for their walls, and roof tiles for their roofs. Since in coastal areas the construction load is one of the triggers of land subsidence [2] [3], this decision is undoubtedly wrong.

Finally, the incorrect responses are not the only issue: households are unable to deal with the impacts of land subsidence due to their lack of money. Land subsidence is a continuous process and it has a long-term effect on income. However, the income capacity of some of the affected households-especially fishermen, farmers and farmworkers-was diminishing. Land subsidence had destroyed their sources of income, which further eroded their ability to cover the adaptation costs. Their lack of capacity to effectively respond to the impacts will leave them vulnerable to land subsidence, and responding to the damage will be a never-ending activity. Therefore, since their responses cannot prevent future impacts and/or their income cannot cover the costly and ineffective adaptation measures, households must consider increasing their income capacity leaving the affected areas.

\section{Conclusions}

Unlike single shock disasters, land subsidence has a gradual, and long-term impact on households, which suffer severe and repeated damage. This study shows that land subsidence affects extensive areas and has different consequences for almost all households. For many households, land subsidence has both direct and indirect impacts. In many cases, the direct impacts trigger indirect impacts in the form of social and economic problems. The combination of these types of impacts means that households suffer from impacts of varying severity. Almost three quarters of the affected households in this study had suffered from multiple types of impact. Such households are the most vulnerable to huge potential impacts because they are also vulnerable to other hazards, such as sea level rise, flooding, peat fires and coastal erosion, which are interrelated [11] [24] [32] [42] [53].

Nevertheless, only just over half $(55.3 \%)$ of the affected households in this study had taken measures to reduce their vulnerability to land subsidence. This shows that the response of people to land subsidence is different from that to single-shock disasters. Because immediate responses are not required, affected households can take the measures that their economic capacities allow. The availability of money, knowledge of land subsidence, information about ways to reduce their vulnerability and the perception of the impacts, fundamentally influence a household's response to land subsidence. This article confirms that households with less income will suffer more [29] [32] [40] [54] [55].

This article also argues that responses must be accompanied by a stable and 
sufficient economic capacity. Although some of the affected households had been able to take measures, namely short-term solutions and adaptations, the situation will remain problematic especially for about the one third of the affected households whose sources of income have also been ruined. As land subsidence has reduced the households' earning capacity, their ability to pay for measures has also been weakened. It supports the studies by Alwang et al. [37], Cutter et al. [36] and Siagian et al. [28] that show the economic capacity of affected households is vital to increase their ability to take measures. The case of land subsidence as a long-term disaster shows that economic capacity is even more critical since the affected households must keep spending money over a long period of time.

To conclude, the fact that land subsidence costs a lot of time and money cannot be ignored, and repeated measures need to be taken over a long period of time. This research shows that even though the affected households have responded to the impacts using their economic capacity, the problems remain. Therefore, to avoid more severe consequences, households must consider increasing their income from other sources or taking adaptive measures based on a proper understanding of the characteristics and impacts of land subsidence. However, this article strongly suggests that proper measures need to be considered by the affected households to avoid the bottomless pit of land subsidence. To do so, they must consider increasing their income capacity, taking more preventive measures or even leaving the affected areas.

\section{Acknowledgements}

The authors would like to thank Thomas Hartmann for his valuable comments in the first draft of this article and Ton Markus for the map.

\section{Conflicts of Interest}

The authors declare no conflicts of interest regarding the publication of this paper.

\section{References}

[1] Galloway, D., Jones, D.R. and Ingebritsen, S.E. (1999) Land Subsidence in the United States. US Geological Survey, Reston, VA.

[2] Marfai, M.A. and King, L. (2007) Monitoring Land Subsidence in Semarang, Indonesia. Environmental Geology, 53, 651-659.

https://doi.org/10.1007/s00254-007-0680-3

[3] Abidin, H.Z., Andreas, H., Gumilar, I., Fukuda, Y., Pohan, Y.E. and Deguchi, T. (2011) Land Subsidence of Jakarta (Indonesia) and Its Relation with Urban Development. Natural Hazards, 59, 1753-1771. https://doi.org/10.1007/s11069-011-9866-9

[4] Phien-Wej, N., Giao, P. and Nutalaya, P. (2006) Land Subsidence in Bangkok, Thailand. Engineering Geology, 82, 187-201.

https://doi.org/10.1016/j.enggeo.2005.10.004 
[5] Gambolati, G., Putti, M., Teatini, P. and Stori, G.G. (2006) Subsidence Due to Peat Oxidation and Impact on Drainage Infrastructures in a Farmland Catchment South of the Venice Lagoon. Environmental Geology, 49, 814-820. https://doi.org/10.1007/s00254-006-0176-6

[6] Wang, J., Gao, W., Xu, S. and Yu, L. (2012) Evaluation of the Combined Risk of Sea Level Rise, Land Subsidence, and Storm Surges on the Coastal Areas of Shanghai, China. Climatic Change, 115, 537-558. https://doi.org/10.1007/s10584-012-0468-7

[7] Chaussard, E., Amelung, F., Abidin, H. and Hong, S. (2013) Sinking Cities in Indonesia: ALOS PALSAR Detects Rapid Subsidence Due to Groundwater and Gas Extraction. Remote Sensing of Environment, 128, 150-161.

https://doi.org/10.1016/j.rse.2012.10.015

[8] Warren, J.P., Jones, L.L., Lacewell, R.D. and Griffin, W.L. (1975) External Costs of Land Subsidence Houston-Baytown Area. American Journal of Agricultural Economic, 57, 450-455. https://doi.org/10.2307/1238407

[9] Yi, L.X., Wang, J., Shao, C.Q., Guo, J.-W., Jiang, Y.X. and Bo, L. (2010) Land Subsidence Disaster Survey and Its Economic Loss Assessment in Tianjin, China. Natural Hazards Review, 11, 35-41. https://doi.org/10.1061/(ASCE)1527-6988(2010)11:1(35)

[10] Yoo, J. and Frederick, T. (2017) The Varying Impact of Land Subsidence and Earth Fissures on Residential Property Values in Maricopa County-A Quantile Regression Approach. International Journal of Urban Sciences, 21, 204-216. https://doi.org/10.1080/12265934.2016.1273129

[11] Abidin, H.Z., Andreas, H., Gumilar, I., Sidiq, T.P. and Gamal, M. (2015) Environmental Impacts of Land Subsidence in Urban Areas of Indonesia. FIG Working Week 2015 from the Wisdom of the Ages to the Challenges of the Modern World, Sofia, 17-21 May 2015, 1-12.

[12] Smit, B. and Pilifosova, O. (2003) Adaptation to Climate Change in the Context of Sustainable Development and Equity. Sustainable Development, 8, 877-912.

[13] Brooks, N. (2003) Vulnerability, Risk and Adaptation: A Conceptual Framework. Tyndall Centre for Climate Change Research Working Paper, Vol. 38, 1-16.

[14] Abidin, H.Z., Andreas, H., Gumilar, I. and Wibowo, I. (2015) On Correlation between Urban Development, Land Subsidence and Flooding Phenomena in Jakarta. Proceedings of the International Association of Hydrological Sciences, 370, 15-20. https://doi.org/10.5194/piahs-370-15-2015

[15] Abidin, H.Z., Andreas, H., Gumilar, I. and Sidiq, T.P. (2016) On Assessment and Estimation of Potential Losses Due to Land Subsidence in Urban Areas of Indonesia. EGU General Assembly Conference Abstracts, Vienna, 17-22 April 2016, 2829.

[16] Xu, Y.-S., Shen, S.-L., Ren, D.-J. and Wu, H.-N. (2016) Analysis of Factors in Land Subsidence in Shanghai: A View Based on a Strategic Environmental Assessment. Sustainability, 8, 573. https://doi.org/10.3390/su8060573

[17] Carbognin, L. and Tosi, L. (2002) Interaction between Climate Changes, Eustacy and Land Subsidence in the North Adriatic Region, Italy. MarineEcology, 23, 38-50. https://doi.org/10.1111/j.1439-0485.2002.tb00006.x

[18] Kreibich, H., van den Bergh, J.C.J.M., Bouwer, L.M., Bubeck, P., Ciavola, P., Green, C., Hallegatte, S., Logar, I., Meyer, V., Schwarze, R. and Thieken, A.H. (2014) Costing Natural Hazards. Nature Climate Change, 4, 303-306. https://doi.org/10.1038/nclimate2182

[19] Lindell, M.K. and Prater, C.S. (2003) Assessing Community Impacts of Natural 
Disasters. Natural Hazards Review, 4, 176-185. https://doi.org/10.1061/(ASCE)1527-6988(2003)4:4(176)

[20] Adger, W.N., Arnell, N.W. and Tompkins, E.L. (2005) Successful Adaptation to Climate Change across Scales. Global Environmental Change, 15, 77-86. https://doi.org/10.1016/j.gloenvcha.2004.12.005

[21] Saputra, E., Hartmann, T., Zoomers, A. and Spit, T. (2017) Fighting the Ignorance: Public Authorities' and Land Users' Responses to Land Subsidence in Indonesia. American Journal of Climate Change, 6, 1-21. https://doi.org/10.4236/ajcc.2017.61001

[22] Marfai, M.A. and King, L. (2008) Coastal Flood Management in Semarang, Indonesia. Environmental Geology, 55, 1507-1518. https://doi.org/10.1007/s00254-007-1101-3

[23] Erkens, G., Bucx, T., Dam, R., De Lange, G. and Lambert, J. (2015) Sinking Coastal Cities. Proceedings of the International Association of Hydrological Sciences, 372, 189-198. https://doi.org/10.5194/piahs-372-189-2015

[24] Hooijer, A., Page, S., Jauhiainen, J., Lee, W.A., Lu, X.X., Idris, A. and Anshari, G. (2012) Subsidence and Carbon Loss in Drained Tropical Peatlands. Biogeosciences, 9, 1053-1071. https://doi.org/10.5194/bg-9-1053-2012

[25] Thorburn, C.C. and Kull, C.A. (2015) Peatlands and Plantations in Sumatra, Indonesia: Complex Realities for Resource Governance, Rural Development and Climate Change Mitigation. Asia Pacific Viewpoint, 56, 153-168. https://doi.org/10.1111/apv.12045

[26] Cutter, S.L. and Finch, C. (2008) Temporal and Spatial Changes in Social Vulnerability to Natural Hazards. Proceedings of the Natural Academy of Sciences of the United States of America, 105, 2301-2306. https://doi.org/10.1073/pnas.0710375105

[27] Füssel, H. (2012) Vulnerability to Climate Change and Poverty. In: Edenhofer, O., Wallacher, J., Lotze-Campen, H., Reder, M., Knopf, B. and Müller, J., Eds., Climate Change, Justice and Sustainability, Springer, New York, 9-17. https://doi.org/10.1007/978-94-007-4540-7_2

[28] Siagian, T.H., Purhadi, P., Suhartono, S. and Ritonga, H. (2014) Social Vulnerability to Natural Hazards in Indonesia: Driving Factors and Policy Implications. Natural Hazards, 70, 1603-1617. https://doi.org/10.1007/s11069-013-0888-3

[29] Adger, W.N. (1999) Social Vulnerability to Climate Change and Extremes in Coastal Vietnam. World Development, 27, 249-269. https://doi.org/10.1016/S0305-750X(98)00136-3

[30] Reuveny, R. (2007) Climate Change-Induced Migration and Violent Conflict. Political Geography, 26, 656-673. https://doi.org/10.1016/j.polgeo.2007.05.001

[31] Loebach, P. (2016) Household Migration as a Livelihood Adaptation in Response to a Natural Disaster: Nicaragua and Hurricane Mitch. Population and Environment, 38, 185-206. https://doi.org/10.1007/s11111-016-0256-9

[32] Harwitasari, D. and van Ast, J. (2011) Climate Change Adaptation in Practice: People's Responses to Tidal Flooding in Semarang, Indonesia. Journal of Flood Risk Management, 4, 216-233. https://doi.org/10.1111/j.1753-318X.2011.01104.x

[33] Koubi, V., Spilker, G., Schaffer, L. and Bernauer, T. (2016) Environmental Stressors and Migration: Evidence from Vietnam. World Development, 79, 197-210. https://doi.org/10.1016/j.worlddev.2015.11.016

[34] Shaw, R., Mallick, F. and Islam, A. (2013) Climate Change: Global Perspectives. In: Shaw, R., Mallick, F. and Islam, A., Eds., Climate Change Adaptation Actions in 
Bangladesh, Springer, New York, 3-14.

https://doi.org/10.1007/978-4-431-54249-0_1

[35] Smit, B. and Wandel, J. (2006) Adaptation, Adaptive Capacity and Vulnerability. Global Environmental Change, 16, 282-292.

https://doi.org/10.1016/j.gloenvcha.2006.03.008

[36] Cutter, S.L., Boruff, B.J. and Shirley, W.L. (2003) Social Vulnerability to Environmental Hazards. Social Science Quarterly, 84, 242-261. https://doi.org/10.1111/1540-6237.8402002

[37] Alwang, J., Siegel, P.B. and Jorgensen, S.L. (2001) Vulnerability: A View from Different Disciplines. The World Bank, Washington DC.

[38] Blaikie, P., Cannon, T., Davis, I. and Wisner, B (2014) At Risk: Natural Hazards, People's Vulnerability and Disasters. Routledge, New York.

[39] Pelling, M. (2010) Adaptation to Climate Change: From Resilience to Transformation. Routledge, New York. https://doi.org/10.4324/9780203889046

[40] Yohe, G. and Tol, R.S.J. (2002) Indicators for Social and Economic Coping Capacity-Moving toward a Working Definition of Adaptive Capacity. Global Environmental Change, 12, 25-40. https://doi.org/10.1016/S0959-3780(01)00026-7

[41] Lubis, A.M., Sato, T., Tomiyama, N., Isezaki, N. and Yamanokuchi, T. (2011) Ground Subsidence in Semarang-Indonesia Investigated by ALOS-PALSAR Satellite SAR Interferometry. Journal of Asian Earth Sciences, 40, 1079-1088. https://doi.org/10.1016/j.jseaes.2010.12.001

[42] Bappenas (2010) Indonesia Climate Change Sectoral Roadmap ICCSR-Scientific Basis: Analysis and Projection of Sea Level Rise and Extreme Weather Event. Bappenas, Jakarta.

[43] Budidarsono, S., Susanti, A. and Zoomers, A. (2013) Oil Palm Plantations in Indonesia: The Implications for Migration, Settlement/Resettlement and Local Economic Development. In: Fang, Z., Ed., Biofuels-Economy, Environment and Sustainability, InTech, London, 173-193. https://doi.org/10.5772/53586

[44] Lee, J.S.H., Abood, S., Ghazoul, J., Barus, B., Obidzinski, K. and Koh, L.P. (2014) Environmental Impacts of Large-Scale Oil Palm Enterprises Exceed that of Smallholdings in Indonesia. Conservation Letters, 7, 25-33. https://doi.org/10.1111/conl.12039

[45] Tashakkori, A. and Teddlie, C. (2010) SAGE Handbook of Mixed Methods in Social \& Behavioral Research. 2nd Edition, Sage, Thousand Oaks, CA.

[46] Philip, L. (1998) Combining Quantitative and Qualitative Approaches to Social Research in Human Geography-An Impossible Mixture? Environment and Planning $A$, 30, 261-276. https://doi.org/10.1068/a300261

[47] Mechler, R. and Bouwer, L.M. (2015) Understanding Trends and Projections of Disaster Losses and Climate Change: Is Vulnerability the Missing Link? Climatic Change, 133, 23-35. https://doi.org/10.1007/s10584-014-1141-0

[48] Nicholls, R.J. and Cazenave, A. (2010) Sea-Level Rise and Its Impact on Coastal Zones. Science, 328, 1517-1520. https://doi.org/10.1126/science.1185782

[49] UN (2016) The World's Cities in 2016: Data Booklet. Population Division, Department of Economic and Social Affairs, United Nations, New York.

[50] Alam, G.M.M., Alam, K. and Mushtaq, S. (2017) Climate Change Perceptions and Local Adaptation Strategies of Hazard-Prone Rural Households in Bangladesh. Climate Risk Management, 17, 52-63. https://doi.org/10.1016/j.crm.2017.06.006

[51] Paavola, J. and Adger, W.N. (2006) Fair Adaptation to Climate Change. Ecological 
Economics, 56, 594-609. https://doi.org/10.1016/j.ecolecon.2005.03.015

[52] Füssel, H. (2007) Adaptation Planning for Climate Change: Concepts, Assessment Approaches, and Key Lessons. Sustainability Science, 2, 265-275. https://doi.org/10.1007/s11625-007-0032-y

[53] Marfai, M.A., King, L., Singh, L.P., Mardiatni, D., Sartohadi, J. Hadmoko, D.S. and Dewi, A. (2008) Natural Hazards in Central Java Province, Indonesia: An Overview. Environmental Geology, 56, 335-351. https://doi.org/10.1007/s00254-007-1169-9

[54] Kellens, W., Zaalberg, R. and De Maeyer, P. (2012) The Informed Society: An Analysis of the Public's Information-Seeking Behavior regarding Coastal Flood Risks. Risk Analysis, 32, 1369-1381. https://doi.org/10.1111/j.1539-6924.2011.01743.x

[55] Satterthwaite, D., Huq, S., Pelling, M., Reid, H. and Lankao, P.R. (2007) Adapting to Climate Change in Urban Areas: The Possibilities and Constraints in Low- and Middle-Income Nations. IIED, London. 